Review

\title{
Acute Phase Proteins response and their clinical application in veterinary medicine
}

Received: Jan, 2020; Accepted: May, 2020

\author{
Aracelle Elisane Alves ${ }^{1, F r a n c i s c o ~ C l a ́ u d i o ~ D a n t a s ~ M o t a ~}{ }^{1}$, \\ Thais Ayumi Stedile Fujimoto ${ }^{1}$, Wesley Matheus Rocha Sousa ${ }^{1^{*}}$, \\ Paula Alessandra Di Filippo ${ }^{2}$
}

\begin{abstract}
Acute-phase proteins (APP) are a group of blood proteins that the synthesis happens quickly and intensely in response to external or internal challenges, such as infection, inflammation, surgical trauma, or stress. These proteins have been used as biomarkers of inflammation, infection, and trauma in human medicine, but have been relatively under-utilized in the context of veterinary medicine due to the unknown diagnostic possibilities. The purpose of this paper is to update the knowledge about APPs in veterinary medicine, reviewing results from different studies suggesting possible clinical applicability of APPs measurement as a valuable tool for veterinary diagnostic and prognostic.

Keywords: inflammation, biomarkers, trauma
\end{abstract}

\section{Introduction}

Acute-phase proteins (APP) have been used as biomarkers of inflammation, infection, and trauma for decades in human medicine, but have been relatively under-utilized in the context of veterinary medicine due to the unknown diagnostic possibilities.

The APP is the group of blood proteins that the synthesis happens quickly and intensely as a systemic reaction to local or systemic disturbances caused by trauma, infection, stress, surgery, neoplasia, or inflammation the goal of which is re-establishment of homeostasis and healing. The systemic

\footnotetext{
${ }^{1}$ Faculdade de Medicina Veterinária - Universidade Federal de Uberlândia, MG, Brasil.

${ }^{2}$ Faculdade de Medicina Veterinária - Universidade Estadual do Norte Fluminense "Darcy Ribeiro"- RJ.

*Corresponding Author: E-mail: wesley.sousavet@gmail.com
} 
acute-phase response occurs in the first few hours of an acute phase response, protein synthesis within the liver and hepatocyte secretion is drastically

altered, and there are measurable changes in the plasma concentration of several plasma proteins referred to as APP (O'Reilly et al., 2018).

The circulating concentrations of APP are related to the severity of the disorder and the extent of tissue damage in the affected animal.

Significant progress has been made in the detection, measurement, and application of APP as biomarkers in companion and farm animal medicine over recent years. Quantification of their concentration can, therefore, provide diagnostic and prognostic information, if proper timing sampling is assured, as well as useful in the follow up of tissue resolution of traumas or inflammation, as well as in the evaluation of the organic response of the treatment.

Many advances in monitoring the APP response in animals for clinical and experimental purposes have been done (RECZYŃSKA et al., 2018; DARA GONZALEZ et al., 2019). Researchers have established many quantitative APP assays, thereby recognizing the species-related difference of the APP behaviour on some key proteins, and the mechanisms involved (MURATA et al., 2004).

The purpose of this manuscript is to update the knowledge about APPs in veterinary medicine, reviewing results from different studies suggesting possible clinical applicability of APP measurement as a valuable tool for both veterinary diagnostic and prognostic.

\section{Acute Phase Protein response}

In response to a challenge, during the acute phase of inflammation, some proteins increase in their serum concentration, they are denominated positive APP and some proteins decrease in their serum concentration, they are called negative APP. Positive APP are further classified as minor, 
moderate, or major APP according to the magnitude and duration of increase during the APR. Major APP increase 10 to 1,000-fold, moderate APP increase 4 to 10 -fold, and minor APP represent those with only slight 2 to 3 - fold increases (Eckersall et al., 2018).

The negative APP includes albumin, the most abundant constitutive plasma protein, and transferrin. Positive APPs are glycoproteins mainly synthesized by hepatocytes and released into the bloodstream upon their stimulation by pro-inflammatory cytokines. The positive APP is an important set of proteins, including haptoglobin, C-reactive protein, serum amyloid A, ceruloplasmin, fibrinogen, and alpha 1-acid glycoprotein.

Pro-inflammatory cytokines, interleukin-6 (IL-6), tumour necrosis factor-alpha (TNF-alpha) and interleukin 1-beta (IL-1-beta) are the major mediators of APP synthesis in the liver (YOSHIOKA et al., 2002).

\section{Mainly Acute Phase Proteins in veterinary medicine and biological functions}

Haptoglobin (Hp) is an a 2 -globulin with a molecular weight of about $125 \mathrm{kDa}$, and have the ability to increase the stability of the peroxidise activity of haemoglobin to low $\mathrm{pH}$. Dogs have only one subtype of $\mathrm{Hp}$ as compared with humans, who have three Hp, subtypes (Hp 1-1, Hp 2-1, and Hp 2-2), and these structural particularities may be responsible for the divergence of findings in the recognition of canine and feline $\mathrm{Hp}$ by antibodies directed against human Hp (CERÓN; ECKERSALL; MARTÍNEZ-SUBIELA, 2005).

The glycosylation pattern of $\mathrm{Hp}$ can vary in dogs with various inflammatory, autoimmune, and neoplastic diseases. The main function of haptoglobin is linked to the bacteriostatic effect, due to the haptoglobin binds free haemoglobin and the haemoglobin binding property has a bacteriostatic effect as it limits free iron available for bacteria. Moreover, haptoglobin has 
functions related to the host defense response in infection and inflammation, as the stimulation of angiogenesis and granulocyte activity (ALSAAD, 2011).

C-reactive protein (CRP) is a $115 \mathrm{kDa}$ protein, consisting in five subunits. Originally named for its ability to bind the C-polysaccharide of Pneumococcus pneumoniae. CRP functions are dependent on its binding to bacteria and promote the binding of complement, which facilitates bacterial uptake by phagocytes. Other biological CRP functions include the induction of cytokines by monocytes and macrophages, inhibition of chemotaxis, and modulation of neutrophil functions (MURATA et al., 2004).

Free native Serum amyloid A (SAA) is a $180-\mathrm{kDa}$ protein, which is normally found in a complexed form with lipoproteins. It is thought to be the precursor of amyloid protein A, the major protein source of alpha-amyloid, so it is potentially involved in the pathogenesis of amyloidosis and other chronic inflammatory diseases. One of the biological activities is its chemotactic effect on monocytes, polymorphonuclear, and T cells (PETERSEN; NIELSEN; HEEGAARD, 2004).

Alpha 1 acid glycoprotein (AGP) is mainly synthesized and secreted by hepatocytes. Local AGP may contribute to the maintenance of homeostasis by reducing the tissue damage associated with the inflammatory process. Systemic AGP has been reported to bind drugs and to participate in immunomodulation. For example, serum albumin, the most important drugbinding protein, AGP binds with and carries substances of endogenous or exogenous origin such as heparin, histamine, serotonin, and steroids. This capacity might help to keep total drug binding levels unaffected in acute phase responses in which serum albumin, a negative APP, decreases in concentration (MURATA et al., 2004).

Ceruloplasmin (CP) is a cooper-containing ferroxidase that oxidizes toxic ferrous iron to its non-toxic ferric form. Cp is synthesized primarily in the liver, but is also induced at extra-hepatic sites and may act as an antiinflammatory agent by reducing the number of neutrophils attaching to the 
endothelium and by acting as an extracellular scavenger of peroxide (MURATA et al., 2004).

Fibrinogen is a B-globulin present in the plasma of all vertebrates. It is involved in homeostasis, providing a substrate for fibrin formation and tissue repair, and a matrix for the migration of activated cells (LEBRETON, CASINI 2016).

Albumin is the most abundant protein in the blood, constituting 35-50\% of the protein in the plasma of healthy animals. It is the major band observed in serum protein electrophoretograms. Albumin is responsible for about $75 \%$ of the osmotic pressure of plasma and is a major source of amino acids that can be utilized by the animal's body (CERÓN; ECKERSALL; MARTÍNEZSUBIELA, 2005).

Transferrin is a plasma glycoprotein responsible for the transport of iron in the circulation; it has a single polypeptide chain of about 700 amino acids. It is a negative APP and involved in innate immunity, probably by sequestering ferric ions to prevent pathogens and parasites from using nutrients (LAW, 2002).

\section{Acute phase protein response and clinical application in veterinary medicine}

Researches have been focused on a description of the APP in response to numerous situations, in order to better understanding of the profile levels changes and mechanisms involved providing the knowledge of the APP as a useful tool for diagnostic in veterinary medicine helping to improve prognostic (HILLSTROM et al., 2014).

The stress response to surgery involves an array of physiological events in the body, including endocrinological, immunological, and hematological alterations leading to a catabolic state. Even though these functions are beneficial in the acute survival situation, this response may, in fact, have 
negative effects on homeostasis and tissue healing. The surgical stress response is believed to be proportional to the degree of tissue injury caused by the procedure. It is therefore important to choose surgical procedures that minimize the negative impact of surgery on the body. Complications after elective surgery in dogs and cats are not uncommon and have been reported to include hemorrhage, surgical site inflammation or infection, and increased attention to the surgical site (Moldal et al., 2018).

A study was performed by Alves et al., (2010) in queens after ovariectomy by laparoscopy and conventional technique in order to verify the intensity of the inflammatory response by assessing acute phase protein and leukocyte levels. Analyses of collected blood samples were done before and until 144 hours after the surgical procedures. Ceruloplasmin, hemopexin, haptoglobin, and acid glycoprotein were significantly increased $24 \mathrm{~h}$ after conventional ovariectomy at the respective rates of $69.85 \%, 103.49 \%, 117.31 \%$, and $199.06 \%$. After the same post-operatory period, the animals submitted to laparoscopic ovariectomy showed 22.31\%, 46.09\%, 79.77\%, and $74.56 \%$, respectively to the same proteins cited previously (Table 1). During the postoperative period, the group of queens submitted to laparoscopy presented the lowest values as compared with the control group. In this group, there a peak followed by a decrease in white blood cell count was observed within 24 $\mathrm{h}$, while in the laparoscopy group the peak was observed $12 \mathrm{~h}$ after surgery. Table 1: Serum concentration ( $\mathrm{mg} / \mathrm{dl})$ increase of ceruloplasmin, hemopexin, haptoglobin and acid glycoprotein (alpha -acid Glycoprotein) after ovariectomy in queens by either conventional technique or laparoscopy as compared with values before surgery $(0 \mathrm{~h})$. 
Table 1: Serum concentration ( $\mathrm{mg} / \mathrm{dl})$ increase of ceruloplasmin, hemopexin, haptoglobin and acid glycoprotein (alpha -acid Glycoprotein) after ovariectomy in queens by either conventional technique or laparoscopy as compared with values before surgery $(0 \mathrm{~h})$.

\begin{tabular}{|c|c|c|c|c|c|c|c|c|}
\hline Proteins & & & & & & & & \\
\hline & Oh & $12 \mathrm{~h}$ & $24 \mathrm{~h}$ & $48 \mathrm{~h}$ & $72 \mathrm{~h}$ & $96 \mathrm{~h}$ & $120 \mathrm{~h}$ & $144 \mathrm{~h}$ \\
\hline \multicolumn{9}{|c|}{ Ceruloplasmin } \\
\hline G1 & $42.29^{\mathrm{Aa}}$ & $48.80^{\mathrm{Aa}}$ & $69.85^{\mathrm{Ab}}$ & $58.80^{\mathrm{Ab}}$ & $27.52^{\mathrm{Aa}}$ & $27.52^{\mathrm{Aa}}$ & $24.92^{\mathrm{Aa}}$ & $\begin{array}{c}21.70^{\mathrm{A}} \\
\mathrm{a}\end{array}$ \\
\hline G2 & $35.47^{\mathrm{Aa}}$ & $37.41^{\mathrm{Ba}}$ & $22.31^{\mathrm{Bb}}$ & $13.53^{\mathrm{Bc}}$ & $10.83^{\mathrm{Ac}}$ & $05.36^{\mathrm{Bd}}$ & $02.18^{\mathrm{Bd}}$ & $0.18^{\mathrm{Bd}}$ \\
\hline \multicolumn{9}{|c|}{ Hemopexin } \\
\hline G1 & $35.31^{\mathrm{Aa}}$ & $60.86^{\mathrm{Cb}}$ & $103.49^{\mathrm{Cc}}$ & $72.99^{\mathrm{Bb}}$ & $65.98^{\mathrm{Bb}}$ & $49.98^{\mathrm{Cb}}$ & $33.70^{\mathrm{Ab}}$ & $\begin{array}{c}20.61^{\mathrm{A}} \\
\mathrm{b}\end{array}$ \\
\hline $\mathrm{G} 2$ & $32.89^{\text {Aa }}$ & $46.24^{\mathrm{Bb}}$ & $46.09^{\mathrm{Ab}}$ & $38.27^{\mathrm{Aa}}$ & $23.98^{\mathrm{Aa}}$ & $21.13^{\mathrm{Aa}}$ & $05.50^{\mathrm{Bc}}$ & $04.49^{\mathrm{Bc}}$ \\
\hline \multicolumn{9}{|c|}{ Haptoglobin } \\
\hline G1 & $28.2^{\mathrm{Aa}}$ & $82.0^{\mathrm{Cb}}$ & $117.31^{\mathrm{Cc}}$ & $103.80^{\mathrm{Cc}}$ & $88.23^{\mathrm{Bb}}$ & $87.40^{\mathrm{Cb}}$ & $85.82^{\mathrm{Ab}}$ & $\begin{array}{c}19.44^{\mathrm{A}} \\
\mathrm{a}\end{array}$ \\
\hline $\mathrm{G} 2$ & $12.1^{\mathrm{Aa}}$ & $14.92^{\mathrm{Bb}}$ & $79.77^{\mathrm{Ac}}$ & $92.80^{\mathrm{Cc}}$ & $59.35^{\mathrm{Bc}}$ & $58.42^{\mathrm{Cc}}$ & $53.99^{\mathrm{Ac}}$ & $44.25^{\mathrm{Cc}}$ \\
\hline \multicolumn{9}{|l|}{ Acid glicop } \\
\hline G1 & $28.35^{\mathrm{Aa}}$ & $41.60^{\mathrm{Bb}}$ & $199.06^{\mathrm{Cc}}$ & $138.64^{\mathrm{Cc}}$ & $85.06^{\mathrm{Bc}}$ & $58.55^{\mathrm{Cb}}$ & $34.99^{\mathrm{Aa}}$ & $\begin{array}{c}19.44^{\mathrm{A}} \\
\mathrm{a}\end{array}$ \\
\hline G2 & $12.86^{\mathrm{Ba}}$ & $13.56^{\mathrm{Db}}$ & $74.56^{\mathrm{Ac}}$ & $73.89^{\mathrm{Bb}}$ & $68.67^{\mathrm{Bb}}$ & $54.74^{\mathrm{Cb}}$ & $53.05^{\mathrm{Ab}}$ & $\begin{array}{c}45.18^{\mathrm{C}} \\
\mathrm{d}\end{array}$ \\
\hline
\end{tabular}

(G1) group of queens submitted to ovariectomy by conventional technique; (G2) group of queens submitted to laparoscopic technique. Values with different small letters in a row and with different capital letters in a column are statistically significant at $\mathrm{p}<0.05$ (ALVES et al., 2010).

The number of leucocytes was higher in animals submitted to conventional ovariectomy than in animals submitted to laparoscopy. Possibly due to the action of cortisol released in animals under stress, pain and immediate post-operative situation that are observed in both operative procedures but probably more severe when the conventional technique is applied (Table 2). 
Table 2. Leukocytes concentrations in Queens submitted to conventional ovariectomy (G1) or laparoscopic ovariectomy (G2) at different times (hr) after surgery.

\begin{tabular}{cccc}
\hline Periods & $\begin{array}{c}\text { G1 in total } \\
\text { leucocytes } \\
(\text { (x103/uL })\end{array}$ & $\begin{array}{c}\text { G2 in total } \\
\text { leucocytes } \\
\left(\mathrm{x} 10^{3} / \mathrm{uL}\right)\end{array}$ & Reference values* $^{*}$ \\
\hline 0 & $11.1 \pm 2.3^{\mathrm{Aa}}$ & $10.1 \pm 3.8^{\mathrm{Aa}}$ & $9.5 \pm 2.3^{\mathrm{Ab}}$ \\
12 & $16.3 \pm 5.1^{\mathrm{Ba}}$ & $15.6 \pm 5.7^{\mathrm{Ba}}$ & $8.7 \pm 2.8^{\mathrm{Ab}}$ \\
24 & $16.9 \pm 3.9^{\mathrm{Ba}}$ & $13.2 \pm 6.1^{\mathrm{Ba}}$ & $9.1 \pm 1.9^{\mathrm{Ab}}$ \\
48 & $16.0 \pm 4.5^{\mathrm{Ba}}$ & $12.3 \pm 5.7^{\mathrm{Bb}}$ & $9.0 \pm 2.8^{\mathrm{Ab}}$ \\
72 & $16.1 \pm 5.3^{\mathrm{Ba}}$ & $11.0 \pm 2.4^{\mathrm{Ba}}$ & $8.7 \pm 3.1^{\mathrm{Ab}}$ \\
96 & $14.2 \pm 5.8^{\mathrm{Ba}}$ & $10.3 \pm 1.9^{\mathrm{Ba}}$ & $8.2 \pm 3.5^{\mathrm{Ab}}$ \\
120 & $12.6 \pm 4.1^{\mathrm{Ba}}$ & $9.0 \pm 1.8^{\mathrm{Aa}}$ & $8.5 \pm 2.6^{\mathrm{Ab}}$ \\
144 & $13.3 \pm 3.9^{\mathrm{Ba}}$ & $8.6 \pm 2.0^{\mathrm{Ab}}$ & $9.0 \pm 1.9^{\mathrm{Ab}}$ \\
\hline
\end{tabular}

Values with different small letters in a row and with different capital letters in a column are statistically significant at $\mathrm{p}<0.05$; (ALVES et al., 2010).

These results indicate that increase or decrease of acute-phase proteins, as well as white blood cell count, may be a useful indicator to evaluate the inflammatory response induced by these surgical procedures. It is possible that the analysis of these parameters in the post-operative period may be useful in the detection of undesirable alterations, such as inflammation/infection and consequently, in defining a prognosis (ALVES et al., 2010).

Cranial cruciate ligament rupture is a prevalent injury in dogs, and tibial plateau leveling osteotomy (TPLO) is one of the preferred surgical techniques. Surgical site infection is a possible complication following TPLO and measurement of serum acute-phase proteins is suggested to be a way to early recognize and distinguish postoperative infectious complications from normal postoperative inflammatory conditions. 
In a study Löfqvist et al., (2018) investigated the changes in concentrations of the systemic inflammatory markers C-reactive protein (CRP) and serum amyloid A (SAA) following tibial plateau leveling osteotomy (TPLO) in dogs and evaluate if deviations from the changes expectedly induced by the surgical procedure are useful in early detection of post-surgical infections. A characteristic pattern of changes in concentrations of CRP and SAA were observed following TPLO with a significant increase $24 \mathrm{~h}$ postsurgery in all dogs and baseline-concentrations re-established at day 12 , these results confirm the alterations on the APP levels after surgical injury and the utility of measurement as a tool on the prognostic of dogs submitted to TPLO.

In bitches, the APP serum level assessment has been used to early pregnancy diagnosis for appropriate medical assistance insuring normal gestation and indicating abortion of embryonic resorption or interruption of undesirable pregnancy. The APP profile on early pregnancy vary as a consequence of generalized inflammatory reaction due to embryonic endometrial invasion and use alterations as a method for early pregnancy diagnosis. The relationship between hormonal status and acute-phase proteins concentrations has been assessed. In one study weekly serum samples were collected from 20 non-pregnant (NP) and 20 pregnant (P) bitches to determine levels of fibrinogen, haptoglobin, ceruloplasmin, seromucoid, glycoprotein, a2 globulin, progesterone, and estradiol-17b. No correlation was found between the implantation sites formed (number of pups born) and the hepatic stimulus for the APP production. Authors conclude that in bitches, APP can be used as an early pregnancy test from the 3rd week of gestation using the haptoglobin assay (values above $112.42 \mathrm{mg} / \mathrm{dl}$ ), from the 4 th to the 6 th week using the ceruloplasmin test (values above 12:76_5:29 $\mathrm{U} / \mathrm{l}$ ), from the 4 th week for using the alpha-acid glycoprotein test (values above $13.67 \%$ ) and from the 4 th week of gestation using the a2-globulin test (values above $0.61 \mathrm{~g} / \mathrm{dl}$ ). Fibrinogen and seromucoid increased in the pregnant 
group from the 5th to the 6th week, respectively, thus not being suitable as parameters for an early pregnancy diagnosis (VANNUCCHI; MIRANDOLA; OLIVEIRA, 2002).

According to Rota et al., (2019), an increase in CRP concentration has been detected in the first or second trimester of pregnancy in the bitch, followed by a decrease before parturition. A second increase after parturition has been occasionally observed. Implantation of the developing embryo in the endometrium and placental development were suggested as the likely cause of acute phase response and it has also been ascribed as the influence of endocrine hormones during pregnancy. In the past, the analysis of CRP and other APP concentrations was proposed as an approach for early pregnancy diagnosis in the bitch. Although the exact mechanisms responsible for parturition are still to be elucidated. A precise prediction of impending parturition could be very useful to avoid long observation periods and is very important when planning a cesarean section. Serum progesterone concentration decreases before parturition and other easily measurable variables that could allow for determination of the onset of parturition would be very useful in clinical practice. C-reactive protein $(\mathrm{CRP})$ is one of the major acute-phase proteins in dogs and the concentrations of this protein was measured around parturition and to verify whether this protein could be useful, together with progesterone $(\mathrm{P})$ to detect the onset of parturition in bitches. It was possible to notice that the increase in CRP very near the time of parturition and the low magnitude of the increase does not allow for it to be useful in clinical practice to assess the onset of parturition in the bitch.

Dynamic change of APP-serum concentrations in pregnant bitches was also correlated to ultrasound features of concepts as well as gestational age. Serum concentrations of Haptoglobin, AGP, and C-reactive protein were statistically more elevated in pregnant than in unpregnant bitches, from the 4th week of gestation until parturition. The APP did not present correlation with gestational age, as ultrasound measurements did, however, it is possible 
to affirm that their concentrations reached maximum values $(\mathrm{Hp}=11.11 \pm 1.7$ $\mathrm{mg} / \mathrm{dl} ; \mathrm{AGP}=449.44 \pm 146.41 \mathrm{mg} / \mathrm{dl}, \mathrm{CRP}=58.30 \pm 14.69 \mathrm{mg} / \mathrm{dl})$ on the 5 th week (ALMEIDA, 2006).

The APP, Serum C-reactive protein (CRP), serum amyloid A (SAA), haptoglobin, ceruloplasmin and fibrinogen profiles in pregnant dogs as well as in bitches at various stages of the estrus cycle was analyzed to verify the possible relationship(s) among the APPs profile and hormonal status. Ultrasound scanner (concept M/C) was used for pregnancy diagnosis, involving the first and second halves of pregnancy. Proestrus, estrus, diestrus and anestrus stages of sexual cycles were differentiated by use of vaginal cytology and blood progesterone and estradiol 17-b levels. No statistically significant differences were observed between the groups with regard to the serum SAA and CRP concentrations. Haptoglobin, ceruloplasmin and fibrinogen concentrations were elevated in pregnant dogs compared to nonpregnant groups, independently from the pregnancy stage. No statistically significant differences in acute phase protein concentrations in dogs at various stages of oestrus could be detected. Results of this study indicated that ceruloplasmin and fibrinogen levels, in addiction of haptoglobin previously demonstrated may have potential importance in the diagnosis of pregnancy, and acute phase proteins may be used for monitoring the health status of the pregnant dogs (ULUTAS et al., 2008).

An evaluation of the APP is recommended as a helperexamination for diagnosis of inflammatory situation in bitches with pyometra. In order to analyse the profile of blood fibrinogen, serum C-reactive protein (CRP) and leukogram, besides checking the possible correlations among these laboratory indicators in bitches clinically healthy and with pyometra, two groups were studied, one without pyometra and other with pyometra. It was observed that the total number of leukocytes, fibrinogen and CRP were higher for the group of animals with pyometra. High positive correlation was observed between CRP and fibrinogen and the latter with parameters of leukogram. It can be 
concluded that leukocytes, fibrinogen and CRP analysis may be recommended as coadjutants examination in the diagnosis of the inflammatory process of bitches with pyometra (CARVALHO et al., 2008).

A study reported the evolution of serum levels of insulin-like growth factor-1 (IGF-1) and C-reactive protein (CRP) in bitches with ovariohysterectomy after diagnostic of pyometra in comparison with the control group of healthy bitches submitted to the surgery and the results showed that these markers could be useful for assessment of the postoperative period due the serum level of IGF-1 is decreased, whereas CRP is increased during severe inflammation. When inflammation caused by pyometra and surgery was performed, the level of IGF-1 was increased and CRP decreased (DABROWSKI et al., 2015).

In dogs with haemorrhagic gastroenteritis, clinically suspected of canine parvovirus infection, the APP dosage can allow the evaluation of the inflammatory state and also could help to diagnostic establishment (MCCLURE et al., 2013; KOGIKA et al., 2003.) Those proteins allowing a diagnosis of inflammatory process in animals with bone marrow depression and, also, they could be useful in the follow up of tissue trauma repair or inflammation, as well as in the evaluation of the response to treatment. As leukopenia is observed in the initial stage of the canine parvovirus infection, the dosage of APP allows the evaluation of the inflammatory state of infected animals. According to these hypotheses, serum APP (haptoglobin, ceruloplasmin and a-acid glycoprotein) levels were measured in 11 healthy and 11 leukopenic dogs with hemorrhagic gastroenteritis, clinically suspected of canine parvovirus infection.

There was a significant difference, with confidence interval of 99\% (P $<0.01)$ for haptoglobin $(\mathrm{p}<0.0064)$ and $\alpha$-acid glycoprotein $(\mathrm{p}<0.0042)$ and $95 \%$ $(\mathrm{P}<0.05)$ of confidence for the ceruloplasmin $(\mathrm{p}<0.0478)$ as compared with the control group. 
In dogs, C-reactive protein, haptoglobin and serum amyloid A have been identified as valuable diagnostic markers of steroid-responsive meningitis-arteritis, while in cats and cattle alpha-acid glycoprotein, haptoglobin and serum amyloid A have been valuable biomarkers of disease (ECKERSALL; BELL，2010).

Evaluation of electrophoretic profile and albumin in the cerebrospinal fluid of dogs were performed in order to discover variations could contribute to the diagnostic of neurological diseases. Results were similar in healthy dogs and dogs with distemper and no nervous signs, but were significantly increased in the group of dogs with distemper showing nervous signs. The study of CSF protein profile proved useful and contributed significantly on the detection of central nervous system disorders and damages to the bloodbrain barrier during the nervous phase of distemper (GAMA et al., 2007).

Perez (2019) performed the measurement of APP levels can be valuable to determine the efficacy of antiviral therapies and vaccines. From the practical point of view, the ability of APP to reduce viral infectivity has been observed in several virus-host models. The response to invading viruses, and the presence of APP in blood and other specific tissues may be altered after viral infection, in association with an enhancement of the host innate immune response. Changes in APP expression after the administration of antiviral drugs and vaccines have been observed, suggesting the possible use of APP as reporters of the efficacy of antiviral treatments.

In a study using APP to check the inflammatory response in dogs after vaccination with an attenuated $E$. canis and subsequently challenged with a wild E. canis strain. Positive APP levels correlated favourableness with the rickettsial load, body temperature and negatively with the thrombocyte counts. Vaccination with an attenuated $E$. canis strain in an experimental erlichiosis infection resulted in considerably muted APP responses compared to those found in challenged unvaccinated dogs, reflecting a milder innate inflammatory response conferred by protection of the vaccine. These milder 
responses correlated well with the absence of clinical disease and diminished rickettsial load found in the vaccinated dogs post-challenge (RUDOLER, 2015).

Moreover, Escribano et al., (2017) concluded that there are significant changes in the serum proteome of dogs with ehrlichiosis with modifications in proteins related with the acute phase response such as $\mathrm{Hp}$, albumin and acid glycoprotein.

The measurement of APPs as a diagnostic tool to differentiate between feline infectious peritonitis (FIP) and other diseases in cats with body cavity effusions was performed by Hazuchova et al., (2017), and concentrations of the APPs in serum and effusion were significantly different in cats with and without FIP. The best APP to distinguish between cats with and without FIP was acid glicoprotein in the effusion; being particularly if measured useful in differentiating between FIP and other diseases, while Serum amyloid A and Haptoglobin were not. The concentration of all three APPs in some diseases as septic processes, disseminated neoplasia was as high as in cats with FIP; therefore, none of these can be recommended as a single diagnostic test for FIP.

APPs are sensitive markers of inflammation of lungs, and serum Creactive protein (CRP), serum amyloid A (SAA), and haptoglobin concentrations recently has been shown to be a useful diagnostic marker in dogs with bacterial pneumonia. All measured APPs initially were significantly increased, but the magnitude of increase was not correlated to disease severity. C-reactive protein and SAA concentrations decreased rapidly after initiation of antimicrobial treatment. According to the results, the normalization of serum CRP may be used to guide the duration of antibiotic treatment in dogs with BP according to Viitanen et al. (2017).

Parasitic diseases also revealed alterations in APP levels and an increase Serum C-reactive protein (CRP), haptoglobin, serum-amyloid A 
(SAA) of in dogs with malignant esophageal spirocercosis has been reported when compared to benign ones (NIVY, 2014).

Venco et al. (2014) studied if CRP may be a diagnostic and/or prognostic marker in canine heartworm, whether it may be used for staging and monitoring canine heartworm, and whether its concentration depends on worm burden or on pulmonary arterial damage and concluded that the CRP can be used as a marker of endothelial arteritis and pulmonary hypertension in dogs with heartworm.

Acute phase proteins (APPs) have been proposed as useful associated markers for the diagnosis and monitoring of treatment of dogs infected by Leishmania infantum (DAZA GONZÁLEZ et al., 2019). Levels of serum haptoglobin, serum amyloid A (SSA) and C-reactive protein (CRP) from 6 infected beagles, positive by both PCR and parasite culture, were monitored for 7 months post-infection. Dogs were then treated for 3 months with allopurinol (20 mg/kg/day PO). Their response to therapy was followed-up for 11 additional months. Levels of $\operatorname{IgG}$ and $\operatorname{IgM}$ were monitored during 21 months and compared. Two months after experimental infections of dogs with L. infantum amastigotes a significant increase of all studied APPs was observed. One month after the beginning of treatment dog's clinical recovery was associated with a significant decrease of all APPs. CRP concentrations decreased more than $75 \%$ in five dogs and SAA concentrations decreased more than $85 \%$ in all dogs. Hp showed a significant decrease on months 1,2 and 4 after the beginning of the treatment and its concentrations decreased more than $50 \%$ in four dogs by month 1 after treatment initiation. Concentrations measured at 5, 7 and 11 months after initiation of therapy appeared lower than those at 7 months post-infection although the decrease was not statistically significant.

Increase in total IgG and IgM was delayed as compared with APPs and in contrast, these Igs did not decrease with treatment. These studies 
suggested that the increased APP levels can be used as biomarkers of Leishmaniasis severity in dogs (MARTÍNEZ-SUBIELA et al., 2011).

In a retrospective study was evaluate and compare the serum concentration of CRP and ferritin between three possible situations that dogs which undergo leishmaniosis treatment could have: responsive with total recovery, responsive with only clinical recovery but persistent abnormalities in biochemical analytes, and unresponsive with clinical and biochemical changes. All dogs which totally recovered after treatment showed CRP and ferritin values within reference ranges and these values are usually associated with the absence of clinical signs and adequate response to treatment and increased CRP and/or ferritin values could reflect a lack of appropriate response to treatment. All dogs which totally recovered after treatment showed CRP and ferritin values within reference ranges. Most of dogs classified as having only partial clinical remission had CRP and ferritin within the reference range values despite the presence of other biochemical abnormalities such as hyperglobulinemia, hyperproteinemia, or proteinuria. On the other hand, most of dogs in the unresponsive group had increased CRP and ferritin. It can be concluded that CRP and ferritin concentrations within the reference ranges are usually associated with the absence of clinical signs and adequate response to treatment and increased CRP and/or ferritin values could reflect a lack of appropriate response to treatment (MARTÍNEZSUBIELA et al., 2016).

A study in rat liver in vivo an in-depth functional analysis was performed using rich pharmacodynamic proteomic data measured over $66 \mathrm{~h}$ following a single dose of methylprednisolone (MPL). As a result, proteins related to the inflammatory acute-phase response were up-regulated in response to MPL. Functionally-similar proteins showed large diversity in their temporal profiles, indicating complex mechanisms of regulation by corticosteroids which needs further studies (AYYAR et al., 2017). 
Possible applications of the APPs assessing in farm animal clinical assessment have been comprehensively reviewed (FAGLIARI et al., 1998). In cattle, increased serum or plasma haptoglobin concentration was found after experimentally induced inflammation, trauma and also after experimental and natural inflammatory diseases. Bovine $\mathrm{Hp}$ was correlated to the severity of experimental infections with bovine respiratory syncytial virus and spontaneous natural infections with foot-and-mouth disease virus. In a field study, the bovine metabolic disorders, hypocalcemia and ketosis were not associated with increased Hp serum concentrations (SKINNER; BROW; ROBERTS, 1991).

Hp has also been associated with bacterial infection of the uterus and delayed uterine involution (SHELDON et al., 2001). However, it has been reported that $\mathrm{Hp}$ concentrations remain low in acute postpartum metritis, in contrast high concentrations were only seen in cases of severe metritis (HIRVONEN et al., 1999). In dairy cows with toxic puerperal metritis, antimicrobial therapy was associated with a decrease of serum $\mathrm{Hp}$ concentrations. Following surgical castration of 14-month old bulls, a higher plasma Hp concentration has been observed when compared to banded and entire bulls (FISCHER et al., 2001). A higher Hp serum concentration has also been reported following ruminotomy (MORIMATSU et al., 1992). Hp serum concentration increased in experimentally-induced mastitis (HIRVONEN et al., 1999) and in field infections of different etiologies.

In horses, increased $\mathrm{Hp}$ serum or plasma concentration has been observed following surgery (KENT; GOODALL, 1991), experimental inflammations as well as during natural diseases. Non-infectious arthritis (HULTÉN; DEMMERS, 2002) and carbohydrate induced laminitis (FAGLIARI et al., 1998) has also been shown to induce increased concentrations of $\mathrm{Hp}$. In addition, in horses suffering from grass sickness (Equine dysautonomia), an increased serum $\mathrm{Hp}$ concentration has been reported. Following castration complicated by post-operative scrotal infection, 
serum levels of Hp showed peak between three and five days post surgery, these alterations were observed by Kent and Goodall (1991). Hp increase was also observed in horses with colic (DI FILIPPO et al., 2010).

In cattle and humans the magnitude and duration of the APP response have been shown to reflect the severity of infection correlating with the amount of underlying tissue damage and inflammation (JACOBSEN et al., 2004). Therefore, APP levels may serve as indicators of prognosis.

In horses, it has been shown that intra-articular injection of $3 \mu \mathrm{g}$ of lipopolysaccharide (LPS) from Gram- bacteria elicits a larger SAA response than an injection of $1 \mu \mathrm{g}$, suggesting that APP concentrations reflect the extent of the underlying inflammation horses (JACOBSEN; HALLINGTHOMSEN; NANNI, 2006).

In sheep with dystocia, high Hp levels have been shown to indicate dead lambs in uterus and consequently, increased surgical risk and a poor prognosis.

A study in horses with colic had higher APPs levels in non-survivors than in survivors (DI FILIPPO et al., 2010). In critically ill and septic foals, high fibrinogen concentration was among the most significant predictors of mortality (PEEK et al., 2006). Increased plasma concentration has been observed in carbohydrate-induced laminitis (FAGLIARI et al., 1998). Acute phase proteins could also indicate subclinical infections as well as a severity of infection. Thus, APP could be a valuable tool, for example to assess individual convalescence periods for horses recovering from respiratory infections.

Increased serum concentration of SAA has been found in foals during infection with Rhodococcus equi (HULTÉN; DEMMERS, 2002), Equine influenza serotype A2 (H3N8) (HULTÉN et al., 1999), Equine herpes virus serotype 1 and Streptococcus equi. In horses as well as other species, SAA synthesis has been shown to take place in several cell types other than hepatocytes during acute-phase states. This extra-hepatic synthesis occurs particularly in endothelial and epithelial cells of organs communicating with 
the external environment (e.g., the gastro-intestinal tract, mammary glands, and respiratory system), which may suggest that SAA plays a role in hostdefense mechanisms and local protection against invading microorganisms. In horses, APPs are synthesized locally in the mammary gland, in joints and in abdominal cavity (JACOBSEN; HALLING-THOMSEN; NANNI, 2006; DI FILIPPO et al., 2010). Measuring local APP levels improves quality of diagnosis, because it provides information on inflammatory/ infectious status of the particular organ of interest, due to the local APP levels allows and recognition of alterations on the respective organs or tissue. However, this potential has been explored only to a very limited degree, and much more research is needed in this field.

Obesity and metabolic disorders are associated with systemic low-grade chronic inflammation, both in humans and animals. Zak et al., (2020), evaluated the effects of obesity and hyperinsulinemia on individual components of the acute-phase reaction in equine metabolic syndrome (EMS) horses. However there were no differences in cytokine gene expression, circulating cytokine concentrations, or concentrations of acute-phase proteins between the EMS and the control groups. Activin A was positively correlated with post-OST insulin concentrations indicating that this marker of inflammation could warrant further investigation in horses with EMS.

In study with parasite resistance and acute phase protein (APP) response to Haemonchus contortus infection in lambs it was concluded that quantitative measurements of APP responses to $\mathrm{H}$. contortus infection provide valuable diagnostic information for monitoring infection progression and treatment responses in lambs (ZHONG, 2014).

In cattle, an increased SAA serum and plasma concentration has been found following experimentally-induced and naturally occurring inflammation as well as experimental and natural infections. The SAA response during viral respiratory diseases is well described (HEEGAARD et al., 2000). As for Hp, SAA responsiveness is of longer duration in virus- 
bacteria co-infections as compared with viral infection alone. The magnitude and lasting of the response were well correlated with the severity of the clinical signs (HEEGAARD et al., 2000; GANHEIM et al., 2003).

All viruses are common causes of farm animal diseases. APPs are among the first agents of immunity, and their concentrations could be diagnostically relevant. It was verified in the most common ruminant viral diseases, elevated serum amyloid A (SAA) and haptoglobin ( $\mathrm{Hp}$ ) levels in blood serum have been observed. However, since these proteins are the main APPs in many viral infections, it is impossible to use their levels for diagnosing particular infections. Decreased $\mathrm{Cp}$ and albumin expression could help differentiate the bluetongue virus infection from other diseases. Lastly, analysis of SAA levels in blood serum and milk could be helpful in diagnosing small ruminant lentivirus infection (RECZYNSKA et al., 2018).

In pigs infected with swine influenza, the concentrations of CRP, Hp and SAA were significantly increased after infection. The concentrations of CRP, Hp and SAA were higher in pigs with clinical disease. Although not specific, strategic APP measurements may reveal ongoing clinical and subclinical infection. A close relationship between the magnitude of serum APP response with the severity of disease, providing an objective tool for validation the severity of infection. The maximum concentration of SAA in serum was closely correlated with lung score and makes this APP potential indicator for disease progress or estimation of treatment strategy (POMORSKA-MÓL, 2014).

A study in commercial crossbred piglets was performed to compare the APR induced by different vaccination protocols used against Porcine Circovirus (PCV) type-2 and Mycoplasma hyopneumoniae (M.hyo). The vaccines that produced greater increases in RT also produced higher APPs increases. The results found indicate serum APPs concentrations differed according to the vaccine used, which may be useful, along with RT, for 
choosing the vaccine or protocol that produces APR of lower magnitude (HERNÁNDEZ-CARAVACA et al., 2017).

\title{
Conclusion
}

According to literature data, it is possible to suggest that changes in serum APP concentration could be used as important biomarkers associated to animal diseases. APPs have proven to be very useful tool to help early detection of subclinical animal diseases or alterations of their health status, providing predictive information of diseases as illustrated by the manuscripts presented. According to this, it should be expected in a near future, APPs could be more widely used as a diagnostic tool in veterinary medicine.

\section{Resposta das proteínas de fase aguda e sua aplicação clínica em medicina veterinária}

\begin{abstract}
Resumo
As proteínas da fase aguda (PFA) são um grupo de proteínas presentes no sangue, as quais a síntese ocorre de forma rápida e intensamente em resposta a desafios externos ou internos, como infecção, inflamação, trauma cirúrgico ou estresse. Essas proteínas têm sido usadas como biomarcadores de inflamação, infecção e trauma na medicina humana, mas tem sido relativamente subutilizadas no contexto da medicina veterinária devido às possibilidades de diagnóstico desconhecidas. O objetivo deste artigo é atualizar o conhecimento sobre PFAs em medicina veterinária, revisando resultados de diferentes estudos que sugerem uma possível aplicabilidade clínica da mensuração de PFAs como uma valiosa ferramenta para o diagnóstico e prognóstico veterinário.

Palavras-chave: inflamação, biomarcadores, trauma
\end{abstract}




\section{References}

ALMEIDA, A. H. Dinâmica de proteínas de fase aguda e mensurações ultrasonográficas no concepto durante o período gestacional em cadelas da raça boxer. 2006. 110 f. Tese (Doutorado em Ciências) - Faculdade de Medicina Veterinária e Zootecnia, Universidade de São Paulo, São Paulo, 2006.

ALSAAD, K. M. Evaluation of Hemogram, Haptoglobine and Clotting Factors Indices in Cattle Affected with Acute and Chronic Peritonitis. Journal of Animal and $\begin{array}{lllllll}\text { Veterinary Advances, } & \text { v. } & 10, & \text { n.1, } & \text { p. } & 11-17,\end{array}$ https://doi.org/10.3923/javaa.2011.11.17

ALVES, A. E.; RIBEIRO, A. P. C.; DI FILIPPO, P. A.; APPARICIO, M. F.; FAGLIARI, J. J.; Vicente, W. R. R. Leucogram and serum acute phase protein concentrations in queens submitted to conventional or videolaparoscopic ovariectomy. Brazilian Journal of Veterinary Research and Animal Science, v.62, n.1, p. 86-91, 2010. https://doi.org/10.1590/S0102-09352010000100012

AYYAR, V. S.; ALMON R. R.; DUBOIS D. C.; SUKUMARAN, S.; QU J.; JUSKO W. J. Functional proteomic analysis of corticosteroid pharmacodynamics in rat liver: Relationship to hepatic stress, signaling, energy regulation, and drug metabolism. Journal Proteomics, v. 160, p. 84-105, 2017. https://doi.org/10.1016/j.jprot.2017.03.007

CARVALHO, C. D. C; RÊGO, E. W. B; QUEQUE, M.; SOARES, P. C. Avaliação da proteína $\mathrm{C}$ reativa, fibrinogênio e leucograma em cadelas com e sem piometra. Medicina Veterinária, v.2, n.2, p. 1-8, 2008.

CERÓN, J. J.; ECKERSALL, P. D.; MARTÍNEZ-SUBIELA, S. Acute phase proteins in dogs and cats: current knowledge and future perspectives. Veterinary Clinical Pathology, v. 34, n. 2, p. 85-99, 2005. https://doi.org/10.1111/j.1939165X.2005.tb00019.x 
DABROWSKI, R.; SZCZUBIAL, M.; KOSTRO, K.; WAWRON, W.; CERÓN J. J.; TVARIJONAVICIUTE, A. Serum insulin-like growth factor-1 and C-reactive protein concentrations before and after ovariohysterectomy in bitches with pyometra. $\begin{array}{lllll}\text { Theriogenology, } & \text { v.83(4), } & \text { p. } & 474-477, & 2015 .\end{array}$ https://doi.org/10.1016/j.theriogenology.2014.09.024

DAZA GONZÁLEZ, M.A.; FRAGÍO, C.; ARNOLD, M.; FERMÍN RODRÍGUEZ, R.; CHECA, A.; MONTOYA, M.; PORTERO FUENTES, C.; RUPÉREZ NOGUER, S.; MARTÍNEZ SUBIELA, J.J.; CERÓN, G. MIRÓ. Effect of two treatments on changes in serum acute phase protein concentrations in dogs with clinical leishmaniosis. The Veterinary Journal, n. 245, p. 22-28, 2019. https://doi:10.1016/j.tvjl.2018.12.020

DI FILIPPO, P. A.; NOGUEIRA, A. F. DA S.; ANAI, L. A.; ALVES, A. E.; SANTANA, A. E.; PEREIRA, G. T. Perfil eletroforético das proteínas séricas e do líquido peritoneal de equinos submetidos à obstrução experimental do duodeno, íleo e cólon maior. Ciência Animal Brasileira, v.11, n.4, p. 938-946, 2010. https://doi.org/10.5216/cab.v11i4.9699

ECKERSALL, P. D.; BELL, R. Acute phase proteins: Biomarkers of infection and inflammation in veterinary medicine. The Veterinary Journal, v. 185, n. 1, p. 23-27, 2010. https://doi.org/10.1016/j.tvjl.2010.04.009

ESCRIBANO D.; CIHAN HÜ.; MARTÍNEZ-SUBIELA S.; LEVENT P.; KOCATURK M.; AYTUG NILÜ.; CERÓN J.J.; TVARIJONAVICIUTE A.; YILMAZ Z. Changes in serum proteins in dogs with Ehrlichia canis infection. Microbial Pathogenesis (2017). https://doi: 10.1016/j.micpath.2017.10.024

FAGLIARI, J. J.; MCCLENAHAN, D.; EVANSON, O. A.; WEISS, D. J. Changes in plasma protein concentrations in ponies with experimentally induced alimentary laminitis. American Journal of Veterinary Research, v.59, p. 1234-1237, 1998.

FISCHER, A. D.; KNIGHT, T. W.; COSGROVE, G. P.; DEATH, A. F.; ANDERSON, C. B.; DUGANZICH D. M.; MATTHEWS, L. R. Effects of surgical or banding 
castration on stress responses and behavior of bulls. Australian Veterinary Journal, v. 79, p. 279-284, 2001. https://doi.org/10.1111/j.1751-0813.2001.tb11981.x

FOURNIER, T.; MEDJOUBI-N, N.; PORQUET, D.; Alpha-1-acid glycoprotein. Biochimica et Biophysica Acta, 1482, p. 157-171, 2000. https://doi.org/10.1016/S0167$\underline{4838(00) 00153-9}$

GAMA, F. G. V; NISHIMORI, C. T; SOBREIRA, M. R; SANTANA, A. E. Evaluation of electrophoretic profile and albumin quota in the cerebrospinal fluid of dogs with distemper showing or not neurvous signs. Arquivos Brasileiros de Medicina Veterinária e Zootecnia, v. 59, n. 1, p. 77-80, 2007. https://doi.org/10.1590/S0102$\underline{09352007000100013}$

GANHEIM, C.; HULTÉN, C.; CARLSSON, U.; KINDAHL, H.; NISKANEN, R.; WALLER, K. P.; The acute phase response in calves experimentally infected with bovine viral diarrhea virus and/ or Manheimia haemolytica. Journal Veterinary Medicine; v. 50, p. 183-190, 2003. https://doi.org/10.1046/j.1439-0450.2003.00658.x

HAZUCHOVA, K.; HELD, S.; NEIGER, R. Usefulness of acute phase proteins in differentiating between feline infectious peritonitis and other diseases in cats with body cavity effusions. Journal of Feline Medicine and Surgery, v.19, n.8, p. 809-816, 2017. https://doi.org/10.1177/1098612X16658925

HEEGAARD, P. M. H.; GODSON, D. L.; TOUSSAINT M. J. M., TJORNEHOJ, K.; LARSEN, L. E.; VIUFF, B.; RONSHOLT, L. The acute phase response of haptoglobin and serum amyloid A (SAA) in cattle undergoing experimental infection with bovine respiratory syncytial virus. Veterinary Immunology Immunopathology., v. 77, p. 151159, 2000. https://doi.org/10.1016/S0165-2427(00)00226-9

HERNÁNDEZ-CARAVACA, I.; GOURGUES, S. F.; RODRÍGUEZ, V.; ESTRADA, E. D.; CERÓN J. J.; ESCRIBANO, D. Serum acute phase response induced by different vaccination protocols against circovirus type 2 and Mycoplasma hyopneumoniae in 
piglets. Research Veterinary Science, v. 114, p. 69-73, 2017. https://doi.org/10.1016/j.rvsc.2017.03.006

HILLSTROM, A.; HAGMAN, R.; TVEDTEN, H.; KJELGAARD-HANSEN, M. Validation of a commercially available automated canine-specific immunoturbidimetric method for measuring canine C-reactive protein. Veterinary Clinical Pathology, v. 43(2), p. 235-43, 2014. https://doi.org/10.1111/vcp.12150

HIRVONEN, J.; EKLUND, K.; TEPPO, A. M.; HUSZENICA, G.; KULCSAR, M.; SALONIEMI, H.; PYORALA, S. Acute phase response in dairy cows with experimentally induced Escherichia coli mastitis. Acta Veterinary Scandinavia, v. 40, p. 35-46, 1999.

HIRVONEN, J.; HUSZENICA, G.; KULCSAR, M.; PYORALA, S. Acute-phase response in dairy cows with acute postpartum metritis. Theriogenology, v. 51, p. 1071-1083, 1999. https://doi.org/10.1016/S0093-691X(99)80012-0

HULTÉN, C.; DEMMERS, S. Serum amyloid A (SAA) as an aid in the management of infectious disease in the foal: comparison with total leucocyte count, neutrophil count and fibrinogen. Equine Veterinary Journal., v. 34, p. 693-698, 2002. https://doi.org/10.2746/042516402776250360

HULTÉN, C.; SANDGREN, B.; SKIOLDEBRAND, E.; KLINGEBORN, B.; MARHAUG, G.; FORSBERG, M. The acute phase protein serum amyloid A (SAA) as an inflammatory marker in equine Influenza Virus infection. Acta Veterinary Scandinavia, v. 40, p. 323-333, 1999.

JACOBSEN, S; ANDERSEN, P. H.; TOELBOELL T; HEEGAARD, P. M. H. Dose dependency and individual variability of the lipopolysaccharide induced bovine acute phase protein response. Journal Dairy Science, v.87, p. 3330-3339, 2004. https://doi.org/10.3168/jds.S0022-0302(04)73469-4 
JACOBSEN, S; HALLING-THOMSEN, M; NANNI, S. Concentrations of serum amyloid $\mathrm{A}$ in serum and synovial fluid from healthy horses and horses with joint disease. American Journal Veterinary Research, v. 67, p. 1738-1742, 2006. https://doi.org/10.2460/ajvr.67.10.1738

KENT, J. E.; GOODALL, J. 1991. Assessment of animmunoturbidimetric method for measuring equine serum haptoglobin concentrations. Equine Veterinary Journal., v. 23, p. 59-66, 1991. https://doi.org/10.1111/j.2042-3306.1991.tb02716.x

KOGIKA, M. M.; PEREIRA, D. A.; ELIAS, F.; NOTOMI, M. K.; DELAYTE, E. H.; KAWAHARA, R.; HAGIWARA, M. K. Determination of serum haptoglobin, ceruloplasmin and acid glycoprotein in dogs with haemorrhagic gastroenteritis. Ciência Rural, v.33, n.3, p. 513-517, 2003. https://doi.org/10.1590/S0103$\underline{84782003000300019}$

LAW, J. H. Insects, oxygen, and iron. Biochemical and Biophysical Research Communications, v. 292, p. 1191-1195, 2002. https://doi.org/10.1006/bbrc.

$\underline{2001.2015}$

LEBRETON A,; CASINI A. Diagnosis of congenital fibrinogen disorders. Annales de Biologie Clinique (Paris), v.74, n.4, p:405-12, 2016. https://doi.org/10.1684/abc.2016.1167

LÖFQVIST, K.; KJELGAARD-HANSEN, M.; NIELSEN, M.B.M. Usefulness of C-reactive protein and serum amyloid A in early detection of postoperative infectious complications to tibial plateau leveling osteotomy in dogs. Acta Veterinaria Scandinavica, v. 60, n.30, 2018. https://doi:10.1186/s13028-018-0385-5

MARTÍNEZ-SUBIELA, S.; PARDO-MARÍN, L.; TECLES, F.; BANETH, G.; CERÓN J. J. Serum C-reactive protein and ferritin concentrations in dogs undergoing leishmaniosis treatment. Research Veterinary Science, v. 109, p. 17-20, 2016. https://doi.org/10.1016/j.rvsc.2016.09.003 
MARTÍNEZ-SUBIELA, S.; STRAUSS-ᄀAYALI, D.; CERÓN, J. J.; BANETH, B. Acute phase protein response in experimental canine leishmaniosis. Veterinary Parasitology, v.180 (3-4), p. 197-202 2011. https://doi.org/10.1016/j.vetpar.2011.03.032

MCCLURE, V.; VAN-SCHOOR, M.; THOMPSON, P. N.; KJELGAARD-HANSEN, M.; GODDAR, A. Evaluation of the use of serum C-reactive protein concentration to predict outcome in puppies infected with canine parvovirus. Journal American Veterinary Medication Association., v. 243(3), p. 361-366, 2013. https://doi.org/10.2460/javma.243.3.361

MOLDAL, E. R.; KJELGAARD-HANSEN, M. J.; PEETERS, M. E.; ANE NØDTVED, A.; KIRPENSTEIJN, J. C-reactive protein, glucose and iron concentrations are significantly altered in dogs undergoing open ovariohysterectomy or ovariectomy. Acta Veterinaria Scandinavica, v.60, n.32, p. $\quad 1-8,2018$. https://doi.org/10.1186/s13028-018-0384-6

MORIMATSU, M.; SARIKAPUTI, M.; SYOTU, B.; SAITO, M.; YAMAMOTO, S.; NAIKI, M. Bovine haptoglobin: single radial immunodiffusion assay of its polymeric forms and dramatic rise in acute-phase sera. Veterinary Immunology Immunopathology., $\quad$ v. $33, \quad$ p. 365-372, 1992 https://doi.org/10.1016/0165$\underline{\text { 2427(92)90007-D }}$

MURATA, H.; SHIMATA, N.; YOSHIKOA, M. Current research on acute phase proteins in veterinary diagnosis: an overview. The Veterinary Journal, v. 168, p. 2840, 2004. https://doi.org/10.1016/S1090-0233(03)00119-9

NIVY, R.; CALDIN, M.; LAVY, E.; SHAABON, K.; SEGEV, G.; AROCH, I. Serum acute phase protein concentrations in dogs with spirocercosis and their association with esophageal neoplasia - a prospective cohort study. Veterinary Parasitology., v. 203, n. 1-2, p. 153-159, 2014. https://doi.org/10.1016/j.vetpar.2014.02.001 
O’REILLY, E. L.; BAILEY, R. A.; ECKERSALL, P. D. A comparative study of acutephase protein concentrations in historical and modern broiler breeding lines. Poultry Science, n.97, p. 3847-3853, 2018. https://doi.org/10.3382/ps/pey272

PEEK, S.F.; SEMRAD, S.; MCGUIRK. S. M.; RISEBERG, A.; SLAC, J. A.; MARQUES, F.; COOMBS. D.; LIEN, L.; KEULER, N.; DARIEN, B. J. Prognostic value of clinic pathologic variables obtained at admission and effect of antiendotoxin plasma on survival in septic and critically ill foals. Journal Veterinary Internal Medicine, v. 20, p. 569-574, 2006. https://doi.org/10.1111/j.1939-1676.2006.tb02898.x

PEREZ. L. Acute phase protein response to viral infection and vaccination. Archives of Biochemistry and Biophysics, v. 671, p. 196-202, 2019. https://doi.org/10.1016/j.abb.2019.07.013

PETERSEN, H. H.; NIELSEN, J. P.; HEEGAARD, P. M. Application of acute phase protein measurements in veterinary clinical chemistry. Veterinary Research, v. 35, n. 2, p. 163-187, 2004. https://doi.org/10.1051/vetres:2004002

POMORSKA-MÓL, M.; KWIT, K.; PEJASK, Z.; MARKOWASKA-DANIEL, I. Analysis of the acute-phase protein response in pigs to clinical and subclinical infection with H3N2 swine influenza virus. Influenza Other Respiratory Viruses, v. 8, n.2, p. 228-234, 2014. https://doi.org/10.1111/irv.12186

RECZYŃSKA, D.; ZALEWSKA, M.; CZOPOWICZ, M.; JAROSŁAW KABA, J.; ZWIERZCHOWSKI, L.; BAGNICKA, E. Acute Phase Protein Levels as An Auxiliary Tool in Diagnosing Viral Diseases in Ruminants-A Review. Viruses, v.10, n.502; p. 1-14. https://doi.org/10.3390/v10090502

ROTA, A.; CHIARA MILANI, C.; CONTIERO, B.; ARTUSI, E.; HOLST, B. S.; ROMAGNOLI, S. Evaluation of serum C-reactive protein concentration as a marker of impending parturition and correlation with progesterone profile in peri-partum bitches. Animal Reproduction Science, v. 204, p. 111-116, 2019. https://doi.org/10.1016/j.anireprosci.2019.03.011 
RUDOLER, N.; HARRUS, S.; MARTÍNEZ-SUBIELA, S.; TVARIJONAVICIUTE, A.; VAN-STRATEN, M.; CERÓN, J. J.; BANETH, G. Comparison of the acute phase protein and antioxidant responses in dogs vaccinated against canine monocytic ehrlichiosis and naive-challenged dogs. Parasitology Vectors, v.8, n.175, 2015. https://doi.org/10.1186/s13071-015-0798-1

SHELDON, I. M.; NOAKES, D. E.; RYCROFT, A.; DOBSON, H. Acute phase protein responses to uterine bacterial contamination in cattle after calving. Veterinary Record., v. 148, p. 172-175, 2001. https://doi.org/10.1136/vr.148.6.172

SKINNER, J. G.; BROW, R. A. L.; ROBERTS, L. Bovine haptoglobin response in clinically defined field conditions. Veterinary Record., v. 128, p. 147-149, 1991. https://doi.org/10.1136/vr.128.7.147

THOMAS, J. S. Overview of plasma proteins. In: FELDMAN, B. F.; ZINKL, J. G.; JAIN, N. C. Schalm's Veterinary Hematology, 5 ed. Lippincott Williams, Wilkins, Philadelphia, p. 891-898, 2000.

ULUTAS, P. A.; BAYAZIT, M.; KIRAL, F.; BILDIK, A. Acute phase protein levels in pregnancy and oestrus cycle in bitches. Research in Veterinary Science, v. 86(3), p. 373-376, 2009. https://doi.org/10.1016/j.rvsc.2008.09.001

VANNUCCHI, C. I.; MIRANDOLA, R. C.; OLIVEIRA, C. M. Acute-phase protein pro le during gestation and diestrous: proposal for an early pregnancy test in bitches. Animal Reproduction Science, v. 74, p. 87-99, 2002. https://doi.org/10.1016/S0378$\underline{4320(02) 00160-4}$

VENCO, L.; BERTAZZOLO, W.; GIORDANO, G.; PALTRINIERI, S. Evaluation of C-reactive protein as a clinical biomarker in naturally heartworm-infected dogs: a field study. Veterinary Parasitology., v. 206, n.1-2, p. 48-54, 2014. https://doi.org/10.1016/j.vetpar.2014.08.018 
VIITANEN, S.J.; LAPPALAINEN, A.K.; CHRISTENSEN, M.B.; SANKARI, S.; RAJAMAKI, M.M. The Utility of Acute-Phase Proteins in the Assessment of Treatment Response in Dogs With Bacterial Pneumonia. Journal Veterinary Internal Medicine, v.31, p.124-133, 2017. https://doi.org/10.1111/jvim.14631

YOSHIOKA, M.; WATANABE, A.; SHIMADA, N.; MURATA, H.; YOKOMIZO, Y.; NAKAJIMA, Y. Regulation of haptoglobin secretion by recombinant bovine cytokines in primary cultured bovine hepatocytes. Domestic Animal Endocrinology, v. 23, p. 425-433, 2002. https://doi.org/10.1016/S0739-7240(02)00174-1

ZAK, A.; SIWINSKA, N.; ELZINGA, S.; BARKER, V.D.; STEFANIAK, T.; SCHANBACHER, B.J.; PLACE, N.J.; NIEDZWIEDZ, A.; ADAMS, A.A. Effects of equine metabolic syndrome on inflammation and acute-phase markers in horses. $\begin{array}{llllll}\text { Domestic Animal Endocrinology, } & \text { v.72, } & \text { p. } & 1-8, & 2020 .\end{array}$ https://doi.org/10.1016/j.domaniend.2020.106448

ZHONG, R. Z.; LI, H. Y.; SUN, H. X.; ZHOU, D.W. Effects of supplementation with dietary green tea polyphenols on parasite resistance and acute phase protein response to Haemonchus contortus infection in lambs. Veterinary Parasitology, v. 205, n.1-2, p. 199-207, 2014. https://doi.org/10.1016/j.vetpar.2014.06.022 